\title{
CYP2C19*10 Allele
}

National Cancer Institute

\section{Source}

National Cancer Institute. CYP2C19*10 Allele. NCI Thesaurus. Code C46012.

Human CYP2C19*10 allele is located within 10q24.1-q24.3 and is approximately $90 \mathrm{~kb}$ in length. This allele, a variant form of the CYP2C19 wild-type allele, encodes cytochrome P450 2C19*10 protein. The CYP2C19*10 allele exhibits a clinically-relevant SNP (c.680C $>T$ ) in exon 5 that results in a $P 227 \mathrm{~L}$ coding change. This alteration in protein sequence severely decreases the enzymatic activity of the cytochrome P450 2C19*10 protein. 